\title{
THE APPLICATION OF ORGANIC HYDROPONICS ON HOMEGROWN URBAN AGRICULTURE IN TAIWAN
}

\author{
YI-HSUAN HSIEH ${ }^{1}$, SSU-PEI LI ${ }^{1} \&$ TING-I LEE ${ }^{2}$ \\ ${ }^{1}$ COMMA Company, Taiwan \\ ${ }^{2}$ Department of Horticultural Science, National Chiayi University, Taiwan
}

\begin{abstract}
The growing method of organic hydroponics has matured in only less than a decade. With this method, hydroponic systems can shift from a conventional approach using inorganic fertilisers, towards a more sustainable way of employing organic fertilisers that are recycled from organic wastes; and thus, fit better into urban agriculture in pursuit of sustainable development. However, the invented method requires at least several weeks for processing and pumping air, to build up enough of a concentration of nitrate in its nutrient solutions. Given that the method might be either more time- or energyconsuming than other urban farming practices, such as conventional hydroponics or organic field farming; this study aims to explore the effects on crop growth of an organic hydroponic system that omits the establishment process for nitrifying bacteria populations or with the removal of aeration in its cultivation period. We conducted hydroponic growing experiments with two variables, using organic fertilisers and giving aeration, to produce lettuce in a backyard of a private townhouse in Chiayi City, Taiwan, in autumn. Because the growth of the entire biomass in the treatment of organic fertilised material with aeration remained stagnant, lettuce were harvested and their weights recorded on the 25th day of the experiment. These experimental results showed that for the inorganic nutrient solution, the yields of the treatment with aeration are higher than those without aeration. On the contrary, for the organic nutrient solution, the yields from the treatment without aeration were higher than those with aeration. This confirms that nitrification is necessary for an organic hydroponic system.
\end{abstract}

Keywords: aeration, bioponics, hydroponics, lettuce, vertical growth systems, urban households, urban cultivation, recycling organic waste.

\section{INTRODUCTION}

In developed cities, organic farming is often adopted by urban agriculture, due to its values for food safety and sustainable development. Among the organic farming operations in urban environments, soil-based or substrate-based methods are very common; whereas hydroponic growing methods are rarely seen. This is not to say that hydroponic growing methods are not suitable for urban agriculture. On the contrary, hydroponic methods have been considered as an efficient approach to apply in the urban environment, due to a high yield per area for crop production such as for lettuces, leafy greens, herbs and tomatoes [1]. Land deficiency is one of the main issues encountered by urban agriculture in highly developed cities, such as New York [2]; thus, hydroponic growing methods in a vertical setup is a solution to this problem, the scarcity of space. Also, use of recycled food or agricultural waste as the organic fertilisers in the hydroponic system can contribute to waste management in an urban environment and its sustainable development.

The reason that organic hydroponics are rarely discussed in urban agriculture is that conventional hydroponic systems cannot, in general, use organic fertilizers. Organic fertilizers cannot be directly used in a conventional system, because they have phytotoxic effects on root growth [3]. In 2011, Shinohara et al. invented an organic hydroponic technique that allows organic fertilisers to be added directly to the nutrient solutions during hydroponic crop growth [4]. 
This hydroponic method also has the beneficial effects of suppressing certain diseases, for example bacterial wilt disease, during the period needed to grow tomato hydroponically [5]. This innovative hydroponic growing method needs microorganisms to mineralize organic nitrogen into nitrate, via ammonification and nitrification; however, the preparation of the organic hydroponic solution designed following the typical method is rather time-consuming. In addition, aeration was required to facilitate the ammonification and nitrification processes, which can increase energy consumption in the technique.

This research aims to explore the possibility of simplifying the preparation procedure for the organic nutrient solutions; thus, decreasing the energy consumption of the hydroponic system, in order to increase the applicability of this system in urban horticulture. In order to maximize land use efficiency, our experimentation used a vertical hydroponic system in the back yard of an urban townhouse. Experiments were conducted to compare the differences in lettuce yields between the use of conventional or organic hydroponic systems, and between these systems being used with and without aeration.

\section{MATERIALS AND METHODS}

\subsection{Vegetable seedlings and the experiment site}

We conducted growth experiments with the loose-leaf lettuce, Lollo Rossa (Lactuca sativa var. crispa from; Known-You Seed Corporation, Kaohsiung, Taiwan). The experiments were undertaken in a triangular back yard of a townhouse in Chiayi City, Taiwan. The site has low light conditions due to shading from the four-story buildings on its south and east sides, only catching sunlight from the northeast side where a $2 \mathrm{~m}$ high wall separates the back yard from an open field (Fig. 1).

During the experimental period between 23 September and 17 October, 2017, light and temperature were not controlled. The average water temperature was recorded on a daily basis as being between $23^{\circ} \mathrm{C}$ and $28^{\circ} \mathrm{C}$, with the mean temperature being $26.3^{\circ} \mathrm{C}$. According

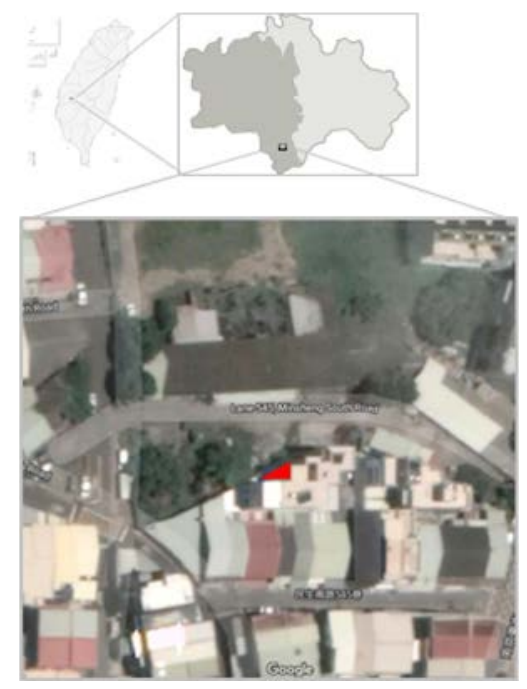

(a)

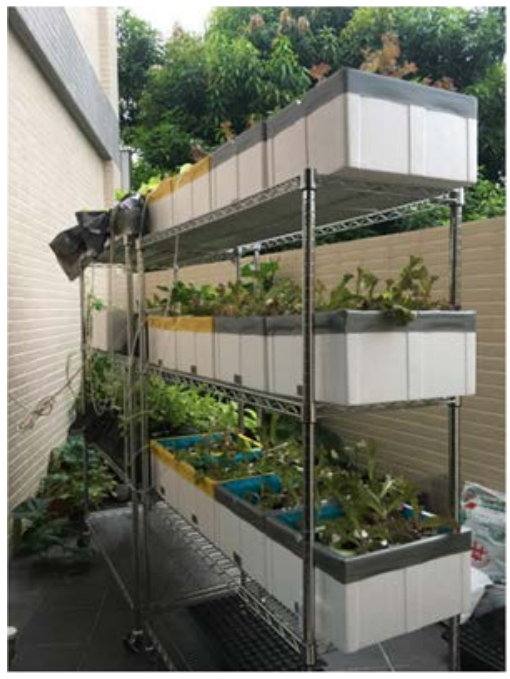

(b)

Figure 1: Lactation of the vertical hydroponic experiments. (a) The red triangle denotes the location of the backyard; (b) The vertical installation (16 October, 2017). 
to the climate data of the Central Weather Bureau, the average temperature of Chiayi was $29.5^{\circ} \mathrm{C}$ in September and $26.2^{\circ} \mathrm{C}$ in October 2017 [4]. The precipitation date and amounts were: $0.4 \mathrm{~mm}$ on 25 September, $47.8 \mathrm{~mm}$ on 29 September, and $4.8 \mathrm{~mm}$ on 5October, $0.2 \mathrm{~mm}$ on 8 October, $1.0 \mathrm{~mm}$ on 9 October, $13 \mathrm{~mm}$ on 13 October, $19 \mathrm{~mm}$ on 14 October, and $41 \mathrm{~mm}$ on 15 October [6].

\subsection{Organic fertilizer as a hydroponic solution}

To prepare the hydroponic solution, we used a method modified from Shinohara et al. [4]: adding fish-based soluble fertilizer at $2 \mathrm{~g}$ per $10 \mathrm{~L}$ of water, then transplanting seedlings to the system on the same day (30 Sept). During our experiments, we also added $2 \mathrm{~g}$ on 7 October; and $4 \mathrm{~g}$ per $10 \mathrm{~L}$ on 14 October. In order to provide additional and minor nutrients, we added $100 \mathrm{~g}$ of oyster shell lime into the solution at the beginning of the experiment.

\subsection{Inorganic fertilizer as a hydroponic solution}

We also conducted conventional hydroponics with an inorganic nutrient solution, modified from the formula developed by the Taichung District Agricultural Research and Extension Station, Taiwan. The formula's composition used in the inorganic treatments was: $\mathrm{Ca}\left(\mathrm{NO}_{3}\right)_{2}$ 236 ppm, KNO3 404 ppm, $\mathrm{NH}_{4} \mathrm{H}_{2} \mathrm{PO}_{4} 57$ ppm, MgSO 4123 ppm, EDTA-Fe 16.04 ppm, EDTA-Mn 0.04 ppm, EDTA-Cu 0.015 ppm, EDTA-Zn 0.015 ppm, B 0.005 ppm, and Mo $0.001 \mathrm{ppm}$.

\subsection{Growth of lettuce with or without aeration}

We conducted growth experiments with lettuce seedlings, with or without use of an aeration pump (YU SHIH FU YS-8000) as a supplement to provide dissolved oxygen (Fig. 2). We raised 8 loose-leaf lettuce seedlings in a polystyrene foam board floating in one hydroponic container (length $37 \mathrm{~cm} \times$ width $32 \mathrm{~cm} \times$ height $19 \mathrm{~cm}$ ) per replicate $(n=3$ replicates per treatment).

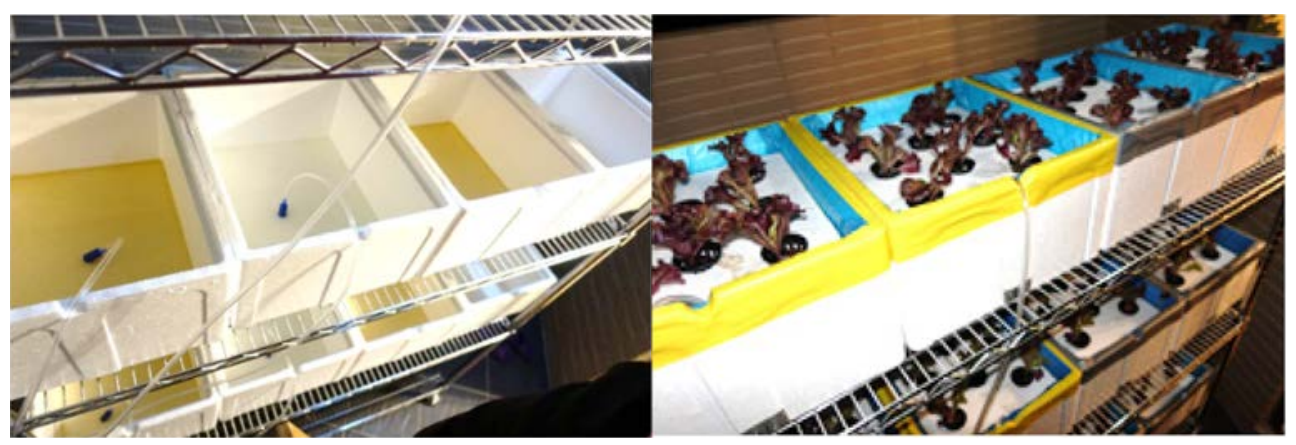

(a)

(b)

Figure 2: The treatments consist of using organic or conventional hydroponic methods, with or without aeration. (a) The nutrient solution of each treatment with or without aeration; (b) The deep floating technique was used in the hydroponic systems. 
West

East

\begin{tabular}{|c|c|c|c|}
\hline Organic with air & $\begin{array}{l}\text { Inorganic with } \\
\text { air }\end{array}$ & $\begin{array}{c}\text { Organic without } \\
\text { air }\end{array}$ & $\begin{array}{c}\text { Inorganic } \\
\text { without air }\end{array}$ \\
\hline A1 & B1 & C1 & D1 \\
\hline A2 & $\mathrm{B} 2$ & $\mathrm{C} 2$ & $\mathrm{D} 2$ \\
\hline A3 & B3 & C3 & D3 \\
\hline
\end{tabular}

Figure 3: Illustration of the configuration of the four treatments and three replicates of the experiments on the vertical hydroponic shelving rack.

\subsection{Vertical installation of the hydroponic system}

Hydroponics systems using conventional and inorganic solutions, with or without aeration, were established in three boxes per treatment. All boxes were placed on a three-tier wire metal shelving rack with its major axis oriented east-west (Fig. 3). The four treatments were coded: A for organic with aeration, B for inorganic with aeration, C for organic without aeration and $\mathrm{D}$ for inorganic without aeration. The three replicates were numbered: 1 was at the top layer, 2 in the middle layer and 3 at the bottom of the shelving rack.

\subsection{Concentration tests for nitrate and ammonium}

An organic hydroponic system relies on nitrification to generate nitrate ions, which can be absorbed directly by plants. When organic fertilisers are added into the nutrient solutions, ammonification comes into play: the organic sources of nitrogen create ammonia. Next, nitrification converts the resulting ammoniums $\left(\mathrm{NH}_{4}{ }^{+}\right)$into nitrites $\left(\mathrm{NO}_{2}{ }^{-}\right)$, and then nitrates $\left(\mathrm{NO}_{3}{ }^{-}\right)$. In order to find out whether the nitrification process acted here, the concentrations of nitrate and ammonium, we tested the nutrient solutions of each treatment on 27 September; 2, 10 and 12 October 2017.

\section{RESULTS}

\subsection{Electrical conductivity and $\mathrm{pH}$}

The electrical conductivity (EC) and $\mathrm{pH}$ values of the nutrient solutions of each hydroponic box were evaluated on a daily basis during the experimental period. EC value test results move along a converging pathway (Fig. 4(a)). In the beginning, the distribution of EC results are at two different levels. One level is between 0.6 and 0.8 , shown by the inorganic treatments (B and $\mathrm{D}$ ); the other one is between 0.2 and 0.4 , shown by the organic treatments (A and C). On average, the EC values of the four treatments also reveal two different levels. The first group consists of A (0.49) and C (0.45); the second group consists of B (0.69) and D (0.71).

With regard to the $\mathrm{pH}$ values, our test results showed a consistent tendency throughout the experimental period (Fig. 4(b)). Among the four treatments, those with aeration were at a higher $\mathrm{pH}$ level (A was 8.07 and $\mathrm{B}$ was 7.62, on average); whereas those without aeration were generally at a lower $\mathrm{pH}$ level (C was 7.29 and D was 7.10, on average). 


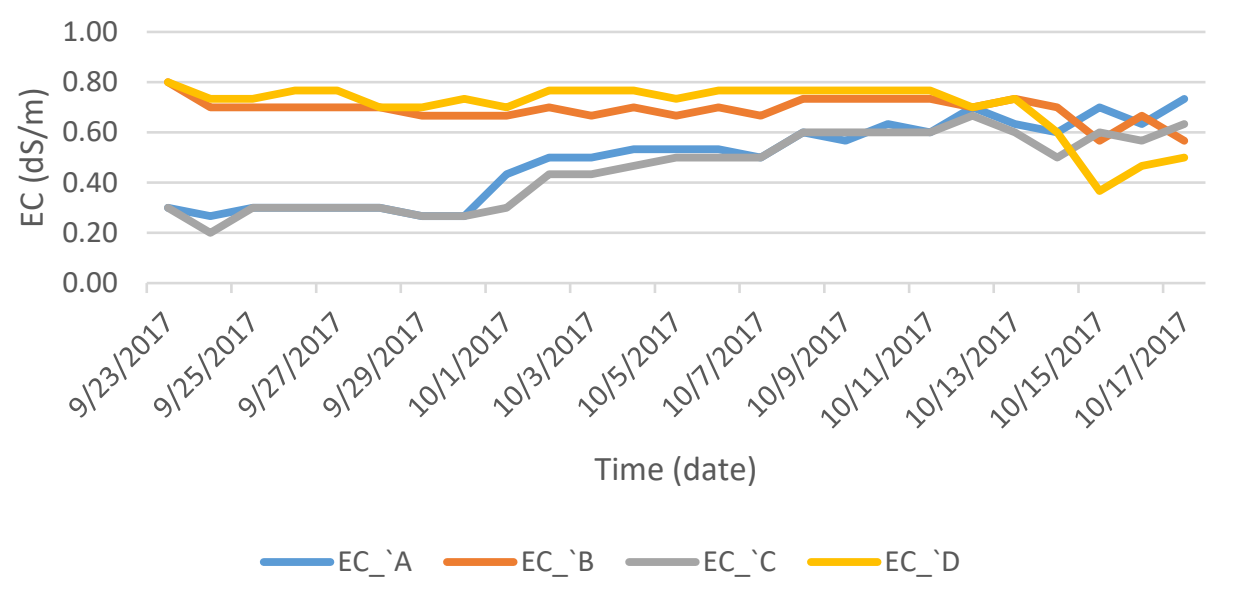

(a)

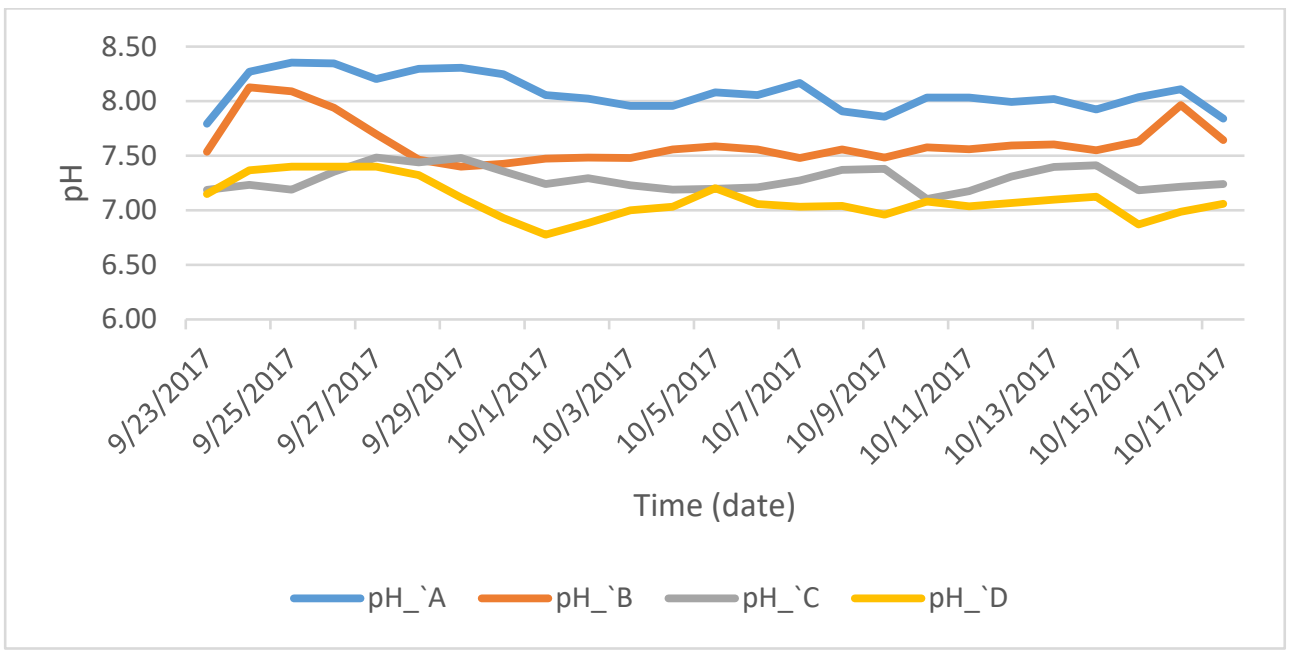

(b)

Figure 4: The mean values of the nutrient solutions by date. (a) EC; (b) pH.

\subsection{The concentrations of nitrate and ammonium}

The tests were conducted every week, for four times in total during the experiment. In general, the nitrate content increased as the ammonium content decreased, in the four treatment solutions (Fig. 5). In comparison, for the concentration of nitrate, the inorganic treatments (B and D) were higher than organic treatments (A and C); while for the concentration of ammonium, the inorganic treatments were at lower values than the organic treatments. Similarly, for the concentration of nitrate, those with aeration treatments (A and B) were higher than those without aeration treatments (C and D); whereas for the concentration of ammonium, those with aeration treatments were lower than those without aeration treatments. 


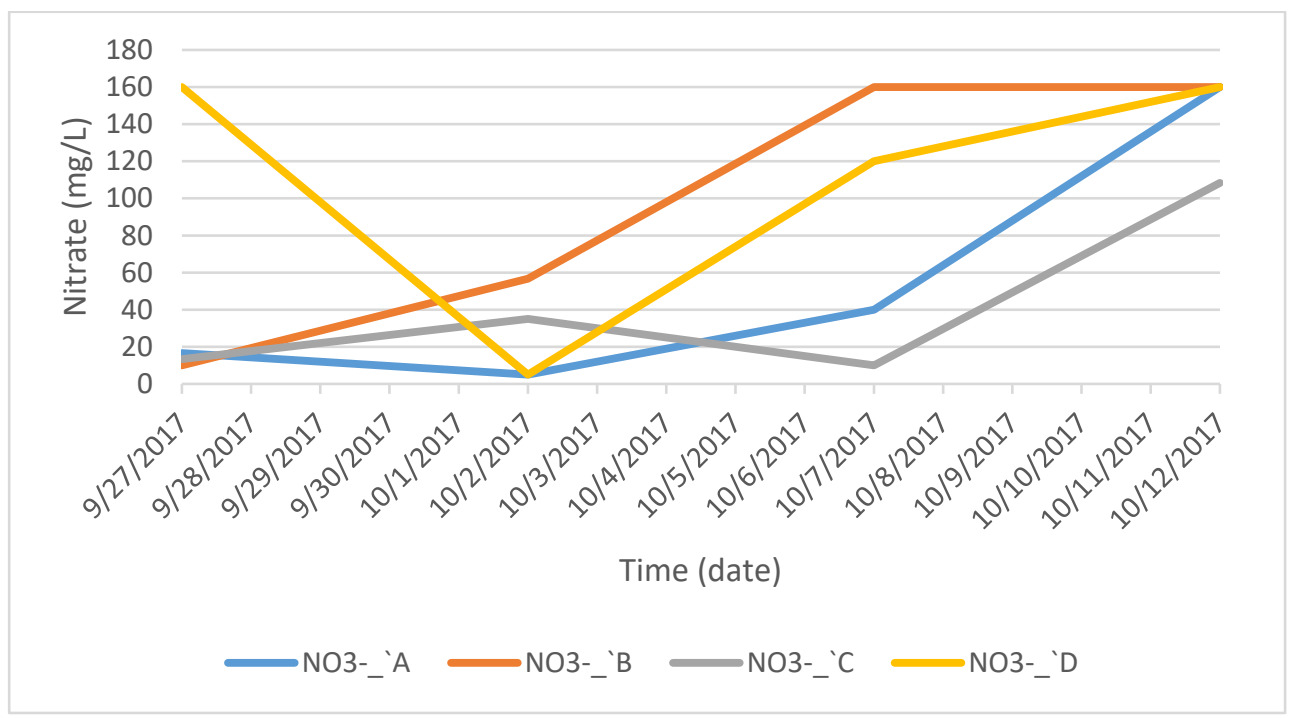

(a)

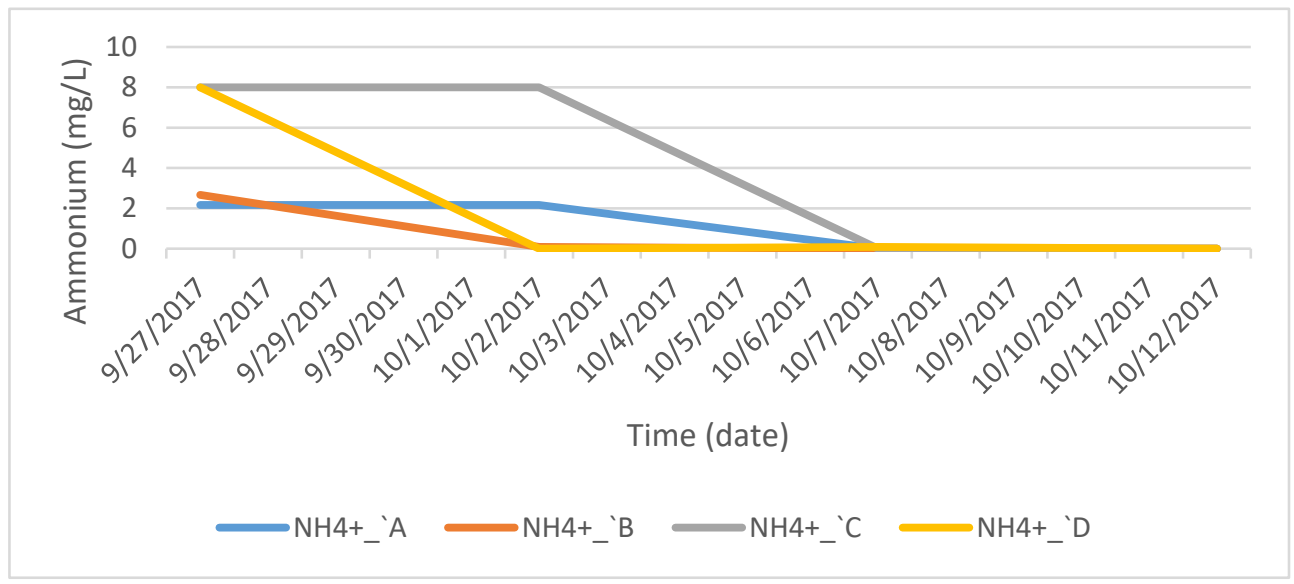

(b)

Figure 5: The mean concentration of the nutrient solutions by date. (a) Nitrate; (b) Ammonium.

\subsection{Yields}

The yields of the treatments using inorganic fertilizers (B and D) are higher than those using organic fertilizers (A and C) (Fig. 6 and Table 1). Furthermore, for the inorganic nutrient solution, the yields of the treatment with aeration (B) are higher than those without aeration (D). On the contrary, for the organic nutrient solution, the yields of the treatment without aeration (C) are higher than those with aeration (A). 


\section{Yield}

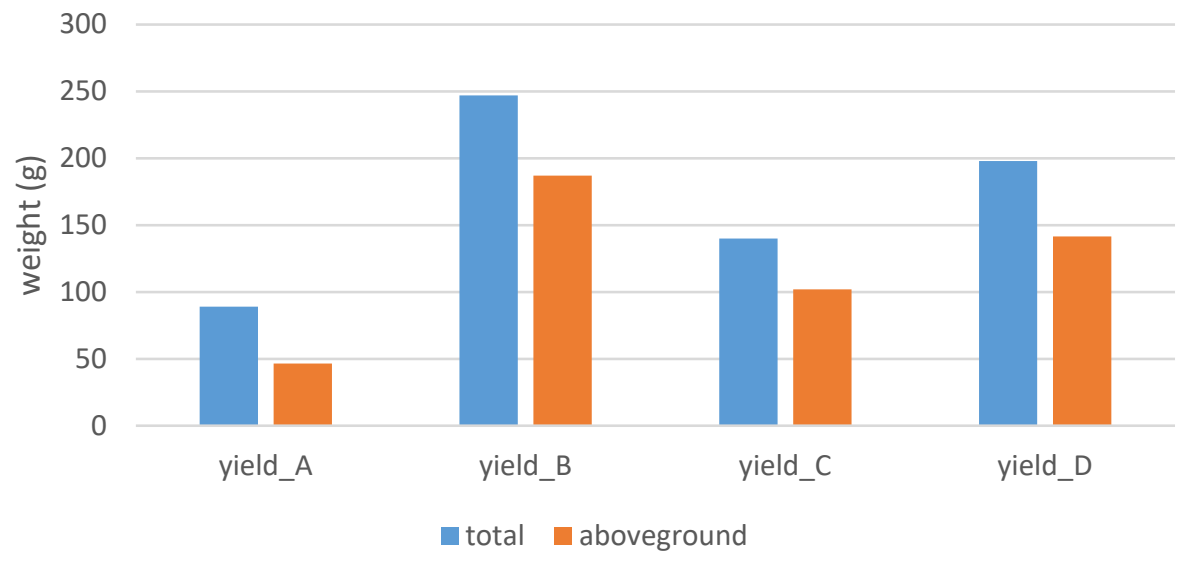

Figure 6: The yields of each treatment and replication (in grams).

Table 1: Yields of each treatment (in grams).

\begin{tabular}{|l|c|c|c|c|}
\hline Harvest total & \multicolumn{4}{|c|}{ Treatments } \\
\cline { 2 - 5 } & $\begin{array}{c}\text { A: Organic, } \\
\text { with aeration }\end{array}$ & $\begin{array}{c}\text { B: Inorganic, } \\
\text { with aeration }\end{array}$ & $\begin{array}{c}\text { C: Organic } \\
\text { without } \\
\text { aeration }\end{array}$ & $\begin{array}{c}\text { D: Inorganic } \\
\text { without } \\
\text { aeration }\end{array}$ \\
\hline Total & 89.0 & 247.0 & 140.0 & 198.0 \\
\hline Aboveground & 46.5 & 187.0 & 102.0 & 141.5 \\
\hline
\end{tabular}

\section{DISCUSSION}

Although most crops prefer to absorb their $\mathrm{N}$ as nitrate nitrogen over ammonium nitrogen, lettuces showed a preference for $\mathrm{NH}_{4}{ }^{+}-\mathrm{N}$ over $\mathrm{NO}_{3}{ }^{-}-\mathrm{N}$ absorption; however, if nitrate nitrogen was not sufficient, use of ammonium as a nitrogen source was not suitable for lettuce, and affected the growth of the lettuce shoots [8]. In this research, the treatments with organic fertilisers did not establish enough of a population of nitrifying bacteria. This research confirms that without enough of a concentration of nitrate nitrogen generated by nitrifying bacteria, the organic treatments tended to have lower yields than those being given inorganic nutrient solutions (Figs 7 and 8).

Interestingly, our results show that when the hydroponic systems were using organic fertilisers with aeration (Treatment A), their yields tend to be the lowest, even lower than those using organic fertilisers without aeration (Treatment $\mathrm{C}$ ). By looking into the $\mathrm{pH}$ value data (Fig. 4(b)), the high alkali level of Treatment A may explain why the crop growth was hindered.

In addition, the EC test results do not seem to be an effective tool to reflect or project the yields, as seen when a comparison was made between organic and inorganic nutrient solutions. It is particularly true when the initially divergent values between the organic and inorganic treatments run in a convergent trend (Fig. 4(a)). The EC values of the organic treatments consistently increased, while those of the inorganic ones dropped at the end of the 


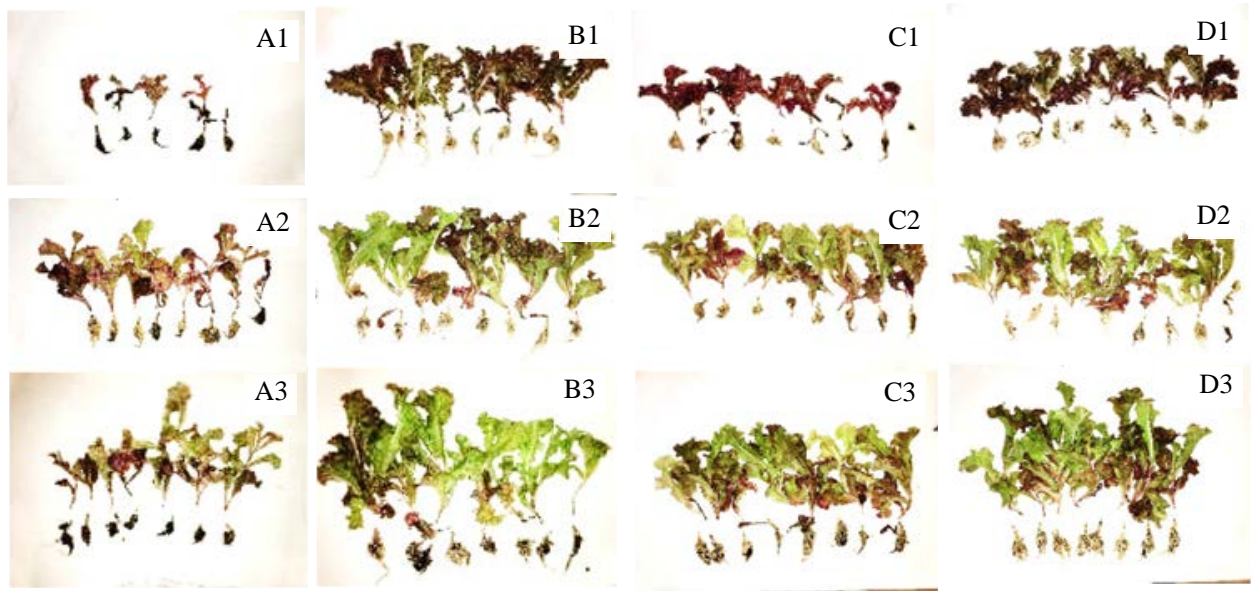

Figure 7: The yields of each treatment in each replication.

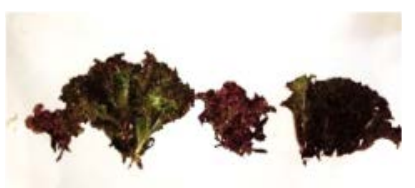

A1、B1、C1、D1

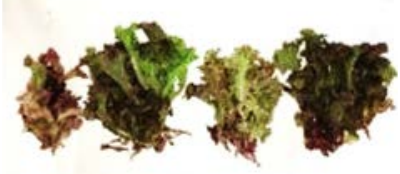

A2、B2、C2、D2

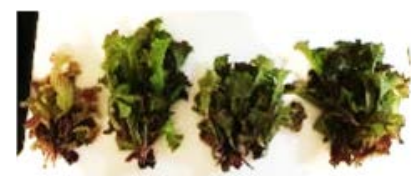

A3 、B3、C3、D3

Figure 8: The total above-ground biomass of each fertiliser treatment group.

experiments. This trend suggested that the organic systems were gradually building up their concentration of absorbable nutrients for crop growth, while the inorganic systems were gradually consuming the absorbable nutrients from the beginning of the experiments. The results confirm the Shinohara et al. finding that nitrification requires time to become established in organic hydroponic systems [4]. As Lee et al. reveal [3], phytotoxic organic acids will affect lettuce growth. If the process is omitted and the lettuce seedlings are placed immediately, without enough nitrate nitrogen, the growth of lettuce seedlings will be affected negatively [8].

In this sense, although the preparation of organic nutrient solutions were rather energyand time-consuming, they seemed to be necessary to generate a balanced ratio of ammonium/nitrate nitrogen for lettuce growth. In this research, it took around three weeks for the EC values and the nitrate concentration of the organic systems to reach a level similar to what the inorganic systems initially have. If seedlings are place into the inorganic systems after a similar level of nitrate concentration is reached, a better yield may be expected for this innovative type of urban agriculture.

\section{ACKNOWLEDGEMENTS}

This research was sponsored by the Innovation Incubation Centre of National Chiayi University in 2017, and it was part of the U-start start-up programme funded by the Youth Development Administration Ministry of Education in 2017. 


\section{REFERENCES}

[1] Ackerman, K., Urban agriculture: Opportunities and constraints. Metropolitan Sustainability, ed. F. Zeman, Woodhead Publishing: Sawston and Cambridge, pp. 118146, 2012.

[2] Campbell, L.K., Getting far,omg pm on the agenda: Planning, policymaking, and governance practices of urban agriculture in New York City. Urban Forestry \& Urban Greening, 19, pp. 295-305, 2016.

[3] Lee, J.G., Lee, B.Y. \& Lee, H.J., Accumulation of phytotoxic organic acids in reused nutrient solution during hydroponic cultivation of lettuce (Lactuca sativa L.). Scientia Horticulturae, 110, pp. 119-128, 2006.

[4] Shinohara, M. et al., Microbial mineralization of organic nitrogen into nitrate to allow the use of organic fertilizer in hydroponics. Soil Science \& Plant Nutrition, 57, pp. 190203, 2011.

[5] Fujiwara, K., Aoyama, C., Tanaka, M. \& Shinohara, M., Suppression of Ralstonia solanacearum bacterial wilt disease by an organic hydroponic system. Journal of General Plant Pathology, 78(3), pp. 217-220, 2012.

[6] Central Weather Bureau (Taiwan), Average Monthly Temperature, Weather Statistic. https://www.cwb.gov.tw/V7/climate/monthlyMean/Taiwan_tx.htm. Accessed on: 29 Sep. 2018.

[7] Central Weather Bureau (Taiwan), Daily Precipitation, Weather Statistics. https://www.cwb.gov.tw/V7/climate/dailyPrecipitation/dP.htm. Accessed on: 29 Sep. 2018.

[8] Tian, X., Li, S., Wang, Z., Yin, X. \& Chen, S., Response of lettuce to different nitrogen forms. Ying Yong Sheng Tai Xue Bao, 14(3), pp. 377-381, 2003 [in Chinese]. 